\title{
Inorganic Geochemical Evaluation of Maastrichtian Coal at Gombe, Gongola Basin, Nigeria: Implications for Resource Potential and Paleoenvironments
}

\author{
Ayoola Y. Jimoh ${ }^{*}$, Olusola J. Ojoº \\ ${ }^{1}$ Department of Geology and Mineral Sciences, Kwara State University Malete, Ilorin Kwara State, Nigeria \\ ${ }^{2}$ Department of Geology, Federal University Oye Ekiti, Ekiti State, Oye-Ekiti, Nigeria \\ Email: *yusuf.jimoh@kwasu.edu.ng
}

How to cite this paper: Jimoh, A.Y. and Ojo, O.J. (2021) Inorganic Geochemical Evaluation of Maastrichtian Coal at Gombe, Gongola Basin, Nigeria: Implications for Resource Potential and Paleoenvironments. International Journal of Clean Coal and Energy, 10, 1-19.

https://doi.org/10.4236/ijcce.2021.101001

Received: November 29, 2018

Accepted: February 25, 2021

Published: February 28, 2021

Copyright $\odot 2021$ by author(s) and Scientific Research Publishing Inc. This work is licensed under the Creative Commons Attribution International License (CC BY 4.0).

http://creativecommons.org/licenses/by/4.0/

\section{(c) (i) Open Access}

\begin{abstract}
The Benue Trough has been known to have great potential for resources such as coal, hydrocarbon, limestone, barite, gypsum, etc. The study area is Maiganga coal mine located at Gombe, Gongola Basin, northern Benue Trough in northeast Nigeria. Two coal seams, shales, siltstones, sandstones, and intercalation of ironstones make up the stratigraphic succession of $35 \mathrm{~m}$ thick. The coal is currently being exploited as a source of fuel at the Ashaka Cement Factory, Ashaka, Gombe state. Elemental and proximate analyses of the coal samples were carried out to investigate coking potential, acid generation potential and its suitability as a source of fuel. The paleodepositional condition and the original plant that form the coal were also examined. The proximate analysis showed that the moisture content ranges from $9.55 \%-11.13 \%$, volatile matter $(40.88 \%$ - $44.89 \%$ dry), ash (5.29\% - 13.99\% dry), fixed carbon $(41.30 \%-53.41 \%$ dry) and calorific value $(5469-6452 \mathrm{kcal} / \mathrm{kg})$. Average values of the major elements; $\mathrm{K}_{2} \mathrm{O}, \mathrm{MgO}$ and $\mathrm{Fe}_{2} \mathrm{O}_{3}$ are low but a high loss on ignition was obtained for the coal ash. The samples recorded low concentrations in the trace elements, except for $\mathrm{Ni}, \mathrm{Cu}, \mathrm{Ba}, \mathrm{Sr}$, and $\mathrm{Zr}$. Coal seam $\mathrm{A}$ exhibits negative europium anomaly and positive cerium anomaly indicating peat vegetation (Sphagnum L.) while coal Seam B showed negative cerium anomaly indicating soil grown plants (Mangrove and Vicia villossa). The present investigation showed that the coals were deposited in fluvial to paralic environments. The coals are not suitable for coking but have potential as a source of fuel and power generation.
\end{abstract}

\section{Keywords}

Coking, Europium, Gombe, Proximate, Vegetation 


\section{Introduction}

The Benue Trough is one of the inland sedimentary basins of Nigeria formed by a rifting process [1]. The trough trends structurally in NNE-SSW direction and extends up to $800 \mathrm{~km}$ in length and $150 \mathrm{~km}$ in width (Figure 1). The sediment fill is up to $6000 \mathrm{~m}$ of Cretaceous-Tertiary age and those pre-dating the mid-Santonian have been deformed, faulted, and uplifted in several places [2]. The Benue Trough is believed to be vestiges of the fragmentations that led to the separation of South America from Africa in the Carboniferous and opening of the South Atlantic through the process of Seafloor spreading consequent to continental up-doming and rifting [1] [3]. The Benue Trough is subdivided into Southern, Central and Northern Benue Trough (Figure 1). The Northern Benue Trough is further

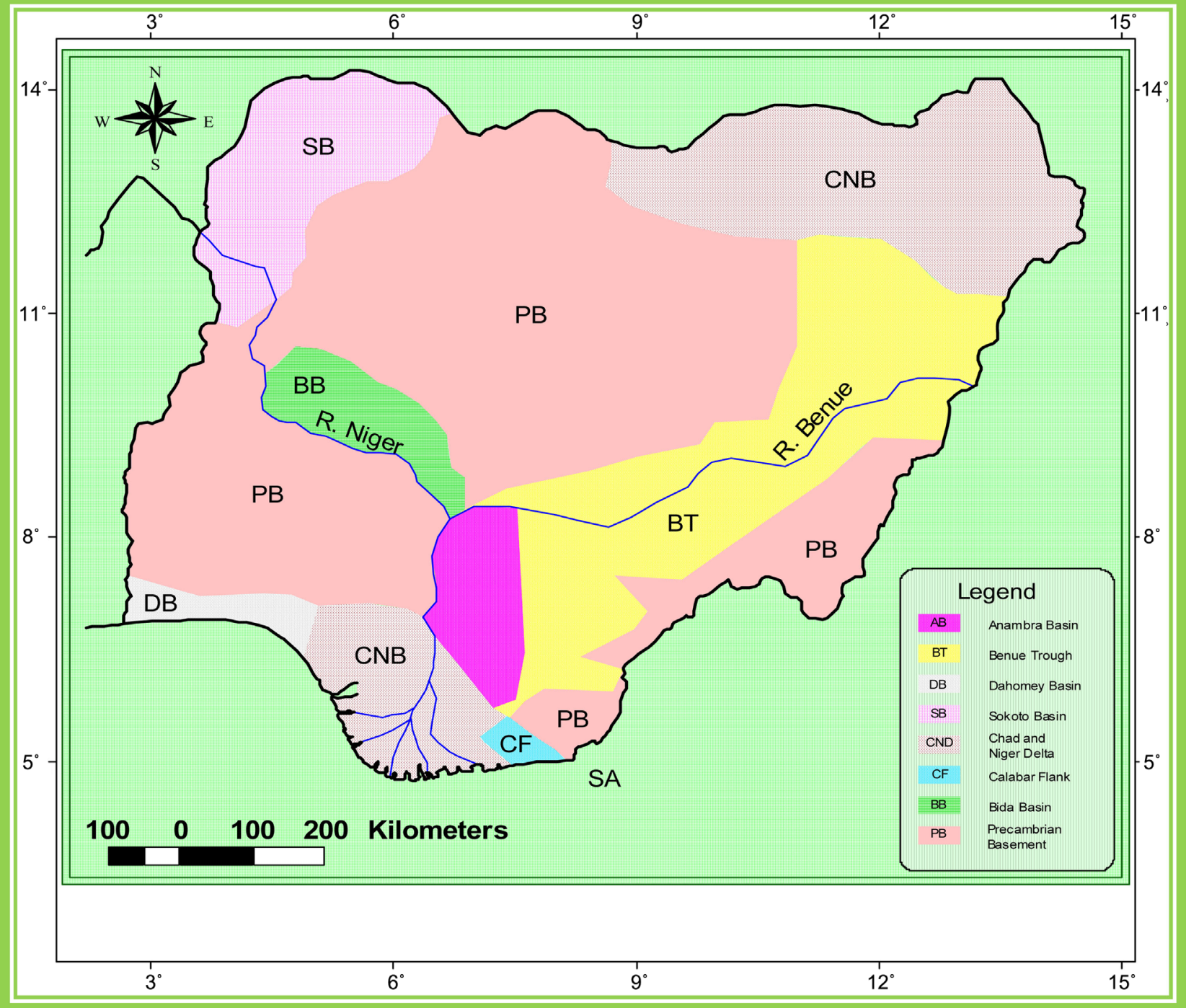

Figure 1. Geological map of Nigeria showing the basement rocks, sedimentary basins and the study location modified after [4]. LEGEND/KEY: AB-Anambra Basin; BT-Benue Trough; DB-Dahomey Basin; SB-Sokoto Basin; ND—Niger Delta; CB-Chad Basin; CF-Calabar Flank; BB-Bida Basin; PB-Precambrian Basement; SBT-Southern Benue Trough; CBT-Central Benue Trough; NBT-Northern Benue Trough; $\square$-Study Area. 
subdivided into Gongola and Yola sub-basins. Huge deposits of coal have been confirmed in Maiganga coal mine in Gombe. The location is bounded by latitude $\left(10^{\circ} 02^{\prime} 39^{\prime \prime} \mathrm{N}\right)$ and longitude $\left(11^{\circ} 12^{\prime} 17^{\prime \prime} \mathrm{E}\right)$. In recent times, certain aspects of the coal deposit have been investigated. These include reports on hydrocarbon generation potential of the coal and stratigraphy of the Gombe Formation [4] [5] [6] [7] [8]. Coal is a fossil fuel derived from decomposition of organic material from plants and animal can be found in various parts of the world e.g. Nigeria, South Africa, U.S.A, Russia, Germany, Australia, China, Indonesia, New Zealand, and India. These deposits are explored and exploited for various uses such as energy generation and sources of fuel. Coals in several basins of the world e.g. Benue Trough in Nigeria, Taranaki basin in New Zealand, Berau basin in Indonesia, Bowen and Galilee basin in Australia have been investigated for hydrocarbon potentials, coking potential, combustibility, power generation, etc., using various geochemical techniques. This paper examines the economic potential of the coal in terms of energy generation, quality of the coal, the depositional condition and the original plant that form the coal based on inorganic geochemical data.

\subsection{The Stratigraphy of Gongola Basin and Lithologic Description of the Coal Mine}

The stratigraphy of Northern Benue Trough (NBT) consists of the oldest, the Basement rocks, Bima Formation, Yolde Formation, Pindiga Formation, Gombe Formation, Kerri Kerri Formation, and the Alluvium [9] (Figure 2). The Aptian-Albian Bima Formation overlies non-conformably on the Precambrian Basement Complex and consists of yellowish-brown, massive cross-bedded feldspathic

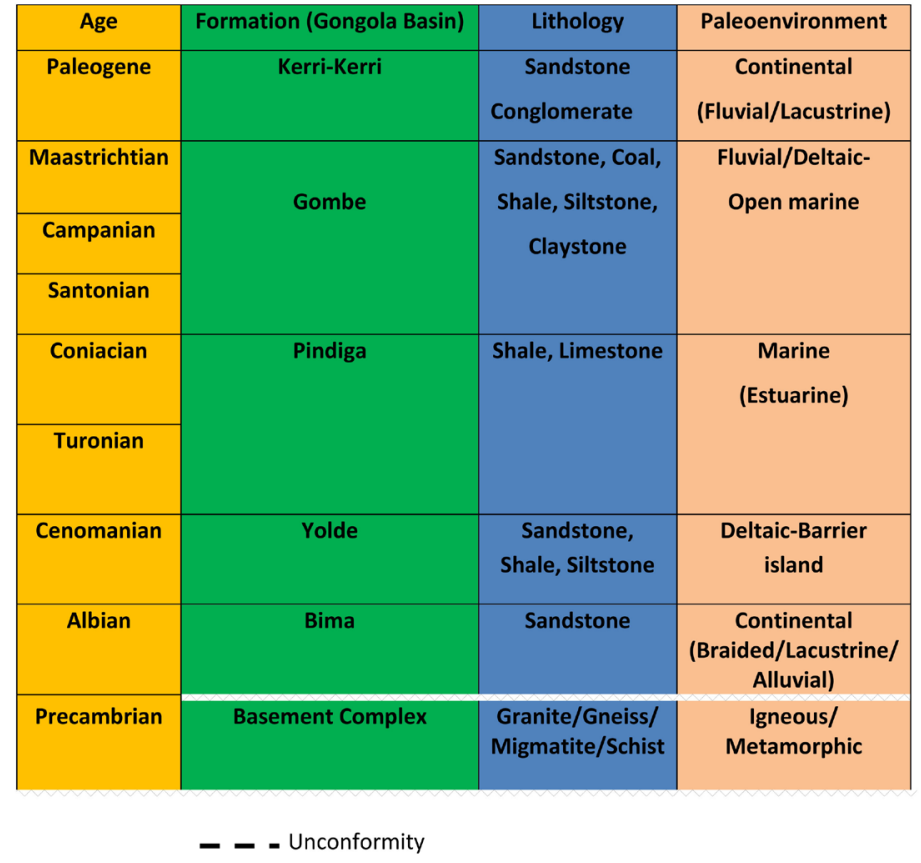

Figure 2. Stratigraphy of Northern Benue trough modified after [16]. 
sandstones [10]. The Yolde Formation (Cenomanian) consists of shales and sandstone which conformably overlies the Bima Formation. Succeeding Bima Formation is the marine shale of the Pindiga Formation (Turonian to Campanian) [11]. The $300 \mathrm{~m}$ thick continental, Campanian-Maastrichtian Gombe Formation overlie the Pindiga Formation which consists of sandstones, shale, siltstones, and ironstones intercalation [12]. Overlying the Gombe Formation is the Tertiary sandstone Kerri-Kerri Formation. The exposed part of the Gombe Formation at the Maiganga mine consists of $35 \mathrm{~m}$ thick coarsening upward section of coal, shale, siltstone, and sandstone (Figure 3 ).

\subsection{Review of Literature}

There are coal occurrences mainly in the Benue Trough of Nigeria and lot of work have been carried out on the coals in aspect of economic geology and petroleum potential. [13] classified coals in the Southern Benue Trough specifically the Mamu Formation as lignite and sub-bituminous. The Lafia/Obi coal in the Central Benue Trough is high volatile bituminous coal while the Gombe coals are lignite and sub-bituminous in rank. The coals in the Southern and Northern Benue Trough are said to be good for combustion and power generation. The coals in the Central Benue Trough are suitable for coking in the steel industry. The combustibility studies of coals carried out by [14] to determine their suitability as source of fuel revealed that Okaba coal in the Southern Benue Trough

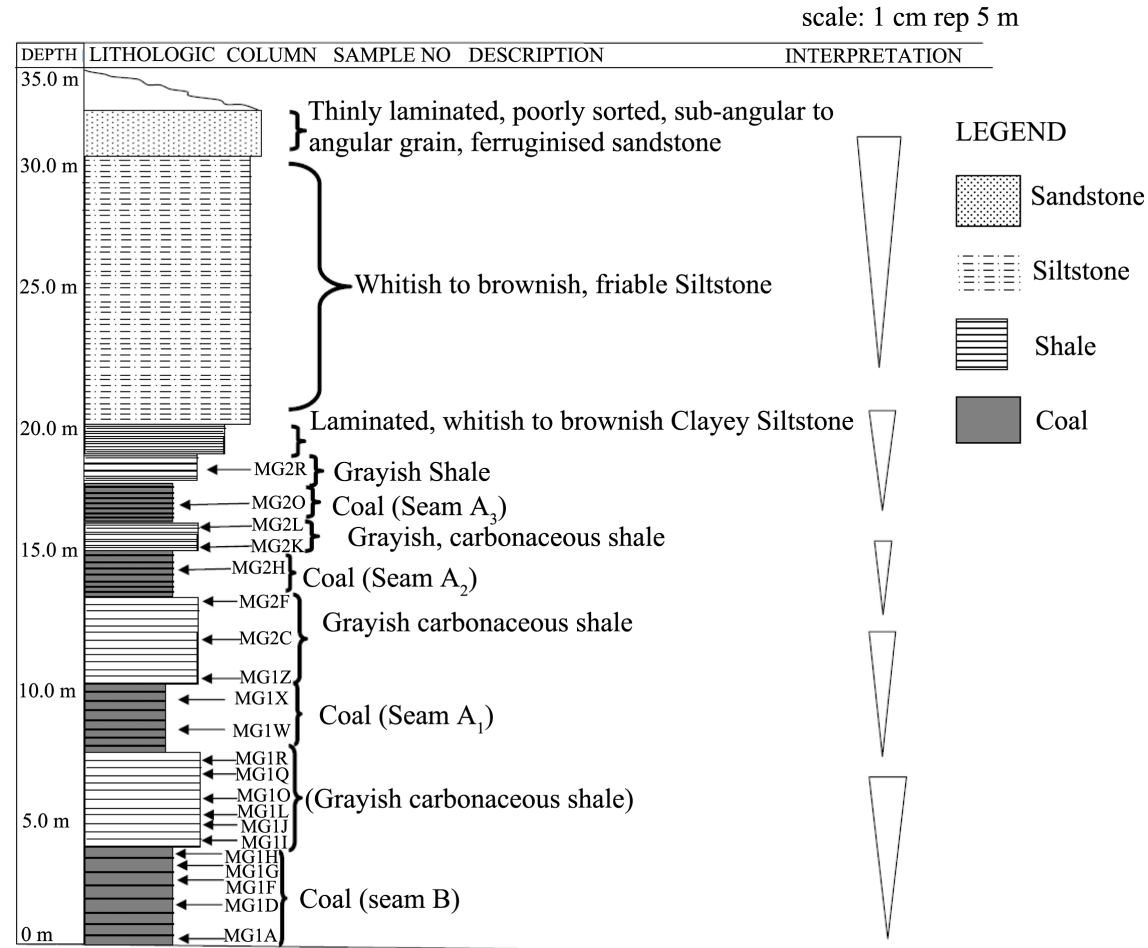

Figure 3. Lithologic succession of Gombe Formation at the Maiganga mine. The succession is $35 \mathrm{~m}$ thick and coarsens upward from coal, shale, siltstone to sandstone indicating a deltaic sedimentation. The shale are interbedded with coal seam A and B $\left(10^{\circ} 02^{\prime} 39^{\prime \prime} \mathrm{N}\right.$, $\left.11^{\circ} 12^{\prime} 17^{\prime \prime} \mathrm{E}\right)$. 
had the shortest combustibility time and thus most suitable for smokeless fuel production and electrical energy generation. It is also characterized by higher values of HI, lowest values of OI and inertinite content when compared to Lafia-Obi coal in the Middle Benue Trough. The acid generation potential of coals in the Benue Trough was also conducted by [15] using analytical techniques such as ICP-OES and Combustion Infra-red (LECO). The study revealed that the high CIA value and low proportion of base neutralizing cations (CNK) in the Benue Trough coals suggest potential to generate acid.

\section{Methodology}

Five coal samples were subjected to proximate analysis to determine the moisture content, volatile matter, ash, fixed carbon and calorific value. Three out of the five coal samples were subjected to whole rock elemental analysis. Both analyses were carried out at Actlab in Canada using standard technique.

\subsection{Proximate Analysis}

\section{Moisture Content}

Determination of moisture was carried out by placing a sample of powdered raw coal of size 200-micron size in an uncovered crucible and placed in the oven between the temperatures of $105^{\circ} \mathrm{C}$ to $110^{\circ} \mathrm{C}$. The samples were cooled to room temperature and weighed again. The loss in weight represents moisture.

\section{Volatile Matter}

Fresh sample of coal was weighed, placed in a covered crucible, and heated in an oven at temperature between $885^{\circ} \mathrm{C}-900^{\circ} \mathrm{C}$. The sample was cooled and weighed. Loss of weight represents moisture and volatile matter.

\section{Ash}

The residue obtained after heating the sample without significant change in weight represent the incombustible ash.

\section{Fixed Carbon}

This is expressed by adding the percentage value of moisture, volatile matter and ash and subtracting from 100. Mathematically, fixed carbon is expressed as, \% C $=100-(\% M+\% V \cdot M+\%$ Ash $)$. Where $M$, represent moisture content, $V . M$ is volatile matter.

\subsection{Whole Rock Elemental Analysis}

Three coal samples were analyzed using inductively coupled Plasma-Mass Spectroscopy (ICP-MS) at ActLab in Canada using standard technique and data was acquired for ten (10) major elements, thirty (30) trace elements and fourteen (14) rare-earth elements. Samples were dried at $\left(60^{\circ} \mathrm{C}\right)$ and sieved to -80 mesh. About $250 \mathrm{~g}$ aliquot was riffle split and pulverized to $85 \%$ passing 200 meshes $(75 \mu \mathrm{m})$ in a mild-steel and puck mill. Major, trace and rare earth elements were analyzed by ICP-MS using $0.25 \mathrm{~g}$ of rock powder fused with $1.5 \mathrm{~g}$ of $\mathrm{LiBO}_{2}$ dissolved in $100 \mathrm{ml}$ of $5 \% \mathrm{HNO}_{3}$. Loss on ignition (LOI) was also determined. 


\section{Results and Discussion}

The results of the proximate and whole rock elemental analysis are presented in Tables 1-4 and Figure 4 and Figure 5.

Table 1. Results of proximate analysis and the calorific values of Maiganga coal.

\begin{tabular}{|c|c|c|c|c|c|c|c|c|}
\hline $\mathrm{S} / \mathrm{N}$ & $\begin{array}{l}\text { Sample } \\
\text { Code }\end{array}$ & Lithology & $\begin{array}{l}\text { Depth } \\
(\mathrm{m})\end{array}$ & $\begin{array}{l}M \\
(\%)\end{array}$ & $\begin{array}{l}\text { V.M } \\
(\%)\end{array}$ & $\begin{array}{l}\text { Ash } \\
(\%)\end{array}$ & $\begin{array}{l}\text { FC } \\
(\%)\end{array}$ & $\begin{array}{l}\text { Calorific value } \\
(\mathrm{kcal} / \mathrm{kg})\end{array}$ \\
\hline \multirow{2}{*}{1} & $\mathrm{MG} \mathrm{A}^{*}$ & Coal & 35 & 11.13 & 38.89 & 4.70 & 44.28 & 5734 \\
\hline & $\mathrm{MG} \mathrm{A}^{\wedge}$ & & & - & 44.89 & 5.29 & 49.83 & 6452 \\
\hline \multirow{2}{*}{2} & $\mathrm{MG} \mathrm{G}^{*}$ & Coal & 30 & 10.00 & 36.79 & 5.14 & 48.07 & 5748 \\
\hline & $\mathrm{MG} 1 \mathrm{G}^{\wedge}$ & & & - & 40.88 & 5.71 & 53.41 & 6387 \\
\hline \multirow{2}{*}{3} & $\mathrm{MG} \mathrm{W}^{*}$ & Coal & 25 & 8.43 & 39.44 & 7.97 & 44.16 & 5573 \\
\hline & $\mathrm{MG} \mathrm{W}^{\wedge}$ & & & - & 43.07 & 8.70 & 48.23 & 6086 \\
\hline \multirow{2}{*}{4} & $\mathrm{MG} \mathrm{H}^{*}$ & Coal & 20 & 14.24 & 37.41 & 6.67 & 41.68 & 5397 \\
\hline & $\mathrm{MG} 2 \mathrm{H} \wedge^{\wedge}$ & & & - & 43.62 & 7.78 & 48.60 & 6294 \\
\hline \multirow{2}{*}{5} & MG2P* & Coal & 17 & 9.55 & 40.44 & 12.65 & 37.36 & 4947 \\
\hline & $\mathrm{MG} \mathrm{P}^{\wedge}$ & & & - & 44.71 & 13.99 & 41.30 & 5469 \\
\hline
\end{tabular}

${ }^{*}=$ As received; $\wedge$ = Dry; $\mathrm{M}-$ Moisture; V.M-Volatile matter; FC—Fixed carbon.

Table 2. Major elements of coal in maiganga mine, Gombe.

\begin{tabular}{|c|c|c|c|c|c|c|c|c|c|c|c|c|c|}
\hline \multirow{2}{*}{$\begin{array}{c}\text { Sample } \\
\text { no }\end{array}$} & Seam & $\mathrm{SiO}_{2}$ & $\mathrm{Al}_{2} \mathrm{O}_{3}$ & $\mathrm{Fe}_{2} \mathrm{O}_{3}$ & $\mathrm{MgO}$ & $\mathrm{CaO}$ & $\mathrm{Na}_{2} \mathrm{O}$ & $\mathrm{K}_{2} \mathrm{O}$ & $\mathrm{TiO}_{2}$ & $\mathrm{P}_{2} \mathrm{O}_{5}$ & $\mathrm{MnO}$ & LOI & Total \\
\hline & \multicolumn{13}{|c|}{$(\%)$} \\
\hline MG1A & Seam A & 1.02 & 0.53 & 0.43 & 0.34 & 1.02 & $<0.01$ & $<0.01$ & 0.046 & $<0.01$ & 0.007 & 96.63 & 100 \\
\hline MG1W & Seam B & 3.38 & 0.79 & 1.37 & 0.37 & 1.11 & 0.02 & 0.01 & 0.107 & 0.01 & 0.045 & 92.76 & 99.97 \\
\hline $\mathrm{MG} 2 \mathrm{H}$ & Seam B & 2.74 & 0.75 & 0.90 & 0.30 & 0.92 & 0.01 & 0.01 & 0.065 & $<0.01$ & 0.025 & 92.26 & 99.99 \\
\hline
\end{tabular}

Table 3. Results of trace elements of coal in Maiganga mine, Gombe.

\begin{tabular}{ccccccccccccccccccccc}
\hline $\begin{array}{c}\text { Sample } \\
\text { no }\end{array}$ & $\mathrm{Ba}$ & $\mathrm{Be}$ & $\mathrm{Co}$ & $\mathrm{Cs}$ & $\mathrm{Ga}$ & $\mathrm{Ge}$ & $\mathrm{Hf}$ & $\mathrm{Nb}$ & $\mathrm{Rb}$ & $\mathrm{Ni}$ & $\mathrm{Sc}$ & $\mathrm{Sn}$ & $\mathrm{Sr}$ & $\mathrm{Ta}$ & $\mathrm{Th}$ & $\mathrm{U}$ & $\mathrm{V}$ & $\mathrm{Y}$ & $\mathrm{W}$ \\
\cline { 2 - 3 } & \multicolumn{10}{c}{$(\mathrm{ppm})$} \\
\hline MG1A & 66 & 2 & $<1$ & $<0.5$ & 5 & $<1$ & $<0.2$ & $<1$ & $<2$ & 111 & 1.0 & $<1$ & 52 & $<0.1$ & 0.5 & 0.3 & $<5$ & 5 & 2.89 \\
MG1W & 91 & $<1$ & 3 & $<0.5$ & 1 & $<1$ & 0.7 & 2 & $<2$ & 121 & 1.1 & $<1$ & 65 & 0.2 & 1.1 & 0.2 & $<5$ & 2 & 2.78 \\
MG2H & 65 & $<1$ & 4 & $<0.5$ & 2 & $<1$ & 0.4 & 1 & $<2$ & 205 & 1.1 & $<1$ & 51 & 0.1 & 0.8 & 0.3 & $<5$ & 2 & 2.63 \\
\hline
\end{tabular}

Table 4. Results of rare-earth elements of coal in Maiganga mine, Gombe.

\begin{tabular}{|c|c|c|c|c|c|c|c|c|c|c|c|c|c|c|}
\hline Sample & $\mathrm{La}$ & $\mathrm{Ce}$ & $\operatorname{Pr}$ & $\mathrm{Nd}$ & $\mathrm{Sm}$ & $\mathrm{Eu}$ & $\mathrm{Gd}$ & $\mathrm{Tb}$ & Dy & Ho & Er & $\mathrm{Tm}$ & $\mathrm{Yb}$ & $\mathrm{Lu}$ \\
\hline no & \multicolumn{14}{|c|}{ (ppm) } \\
\hline MG1A & 1.1 & 2.9 & 0.39 & 1.7 & 0.4 & 0.1 & 0.4 & $<0.1$ & 0.5 & 0.1 & 0.3 & $<0.05$ & 0.3 & 0.05 \\
\hline MG1W & 3.3 & 5.5 & 0.54 & 2.0 & 0.4 & 0.08 & 0.3 & $<0.1$ & 0.3 & $<0.1$ & 0.2 & $<0.05$ & 0.2 & $<0.04$ \\
\hline MG2H & 2.7 & 5.5 & 0.61 & 2.3 & 0.4 & 0.09 & 0.4 & $<0.1$ & 0.3 & $<0.1$ & 0.2 & $<0.05$ & 0.2 & $<0.04$ \\
\hline
\end{tabular}




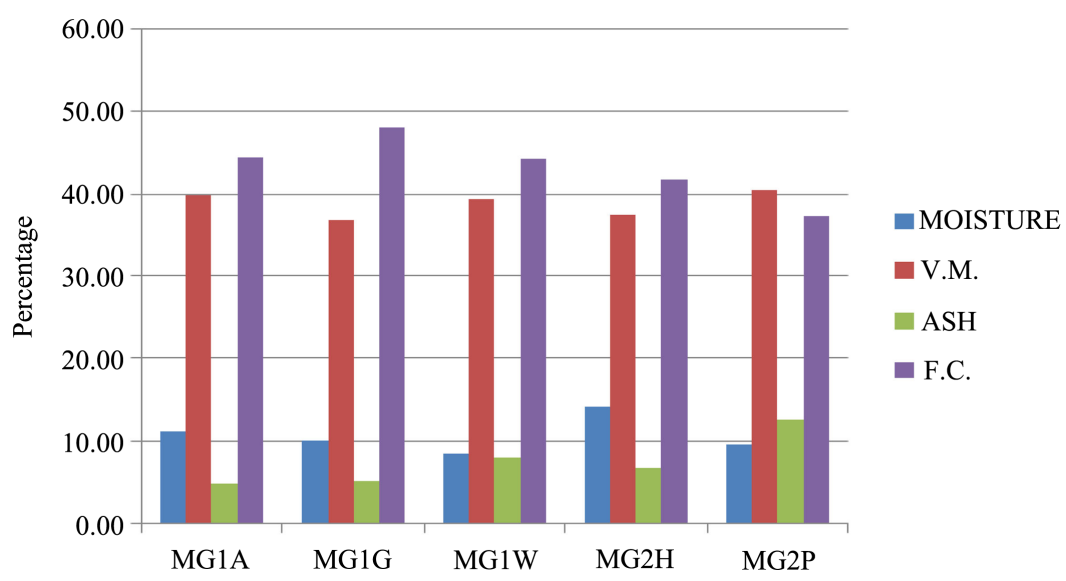

Figure 4. Bar chart showing the percentage of volatile matter, ash and fixed carbon of the coal samples (as received). The samples are characterized by low to medium moisture, high volatile matter with moderate ash content.

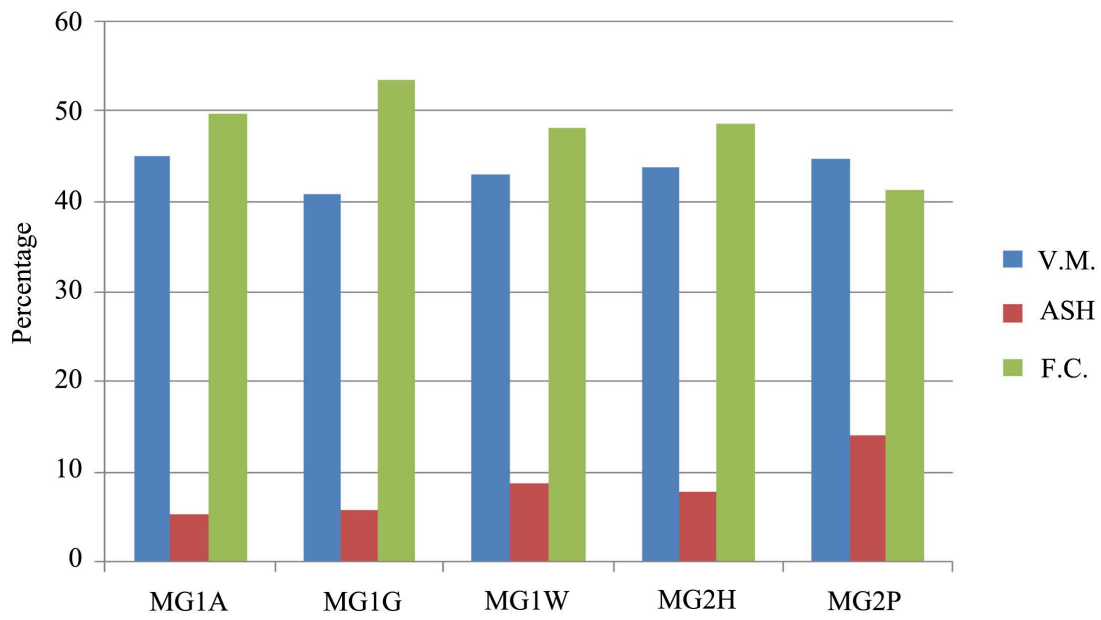

Figure 5. Bar chart showing the percentage of volatile matter, ash and fixed carbon of the coal samples (dry). The samples are characterized by high volatile matter with moderate ash content.

\subsection{Coal Quality}

The percentage of moisture $(M)$, volatile matter (V.M) and ash content and the fixed carbon of all the samples (as received and air-dried) are shown in Table 1 and Figure 4 and Figure 5. Generally the moisture values varied from $(8.43 \%$ 14.24\%). Coal sample MG2H has the highest moisture content (14.24\%) and sample MG1W has the lowest $(8.43 \%)$. The values suggest that coal sample MG2H will take more time to heat and will have lower calorific value [17] since the moisture content is high and hence will be consumed more during heating. Moisture content required for good coking coal is $1.5 \%$ but may range from $1 \%$ $4 \%$ [18]. In the samples analyzed, the moisture content is higher probably due to oxidation and may not be suitable for coking. The results also indicated that other physical properties; volatile matter, ash, fixed carbon and calorific values increase after the moisture content has been driven off (air-dried). 
Volatile matter is the most important parameter used in determining coal rank, suitability, and resource applicability [18]. Data obtained in this study showed that all the samples have high volatile matter which range from $(36.79 \%$ - $40.44 \%$ as received) and (40.88\% - $44.89 \%$ when air dried). As the volatile matter content of coal increases there is a relative decrease in the calorific value of coal from the older beds to the younger beds. It has been suggested in the past that coals with high volatile matter content ignite easily and are highly reactive in combustion applications [18]. High volatile noncoking coal or weakly coking coals are known to have high volatile matter content of $36 \%$. The investigated samples are therefore classified as noncoking coal due to their relatively high volatile matter. Similar results were recorded for coals in Southern Benue Trough that is in Onyeama, Orukpa and Okaba coal [19]. [20] also reported that coal in the Central Benue Trough (Turonian-Coniacian Lafia-Obi coal) has low moisture content, low volatiles, high calorific value $(7500-8500 \mathrm{kcal} / \mathrm{kg})$ and therefore classified as a coking coal.

The Ash content of the investigated samples varies from $(5.29 \%-13.99 \%)$ when air dried. It is observed that as percentage of ash content increases, the heat value or calorific value decreases, i.e. ash content is inversely proportional to the heat value. Low ash content is essential requirement for coke making coal and an ash content of less than $10 \%$ is recommended for coking. In the study samples, only coal sample MG2P has ash content greater than $10 \%$. The low average value of the ash may be due to low amount of inorganic minerals present in the coal ash e.g. quartz, (1.35\%), kaolinite $(1.83 \%)$ and sulphur $(0.07 \%)$. The quartz and kaolinite contents were calculated by [21] using the following mathematical equations. Ash content reduces plasticity and determines the behavior of slag in a combustion chamber.

$$
\begin{gathered}
Q=\mathrm{SiO}_{2}-1.5 \times \mathrm{Al}_{2} \mathrm{O}_{3} \\
K=\mathrm{SiO}_{2}+\mathrm{Al}_{2} \mathrm{O}_{3}+\mathrm{K}_{2} \mathrm{O}-Q+9.1 \times \mathrm{K}_{2} \mathrm{O}
\end{gathered}
$$

MG1A, $Q=1.02-(1.5 \times 0.53) \quad Q=0.225$

MG1W, $Q=3.38-(1.5 \times 0.79) \quad Q=2.195$

MG2H, $Q=2.74-(1.5 \times 0.75) \quad Q=1.615$

MG1A, $K=(1.02+0.53+0.01)-0.225+(9.1 \times 0.01) \quad K=1.43$

MG1W, $K=(3.38+0.79+0.01)-2.195+(9.1 \times 0.01) \quad K=2.08$

MG2H, $K=(2.74+0.75+0.01)-1.615+(9.1 \times 0.01) \quad K=1.98$

Fixed carbon content has a direct relation with the calorific value and varies between $41.30 \%-53.41 \%$ when air dried and $(37.36 \%-48.07 \%$ as received). Table 1 and Figure 4, Figure 5 showed all the samples have high fixed carbon (above 40\%) and it is expected that the calorific value will be high (up to 6452 $\mathrm{kcal} / \mathrm{kg}$ ). Fixed carbon content determines the coke yield of coal samples, for instance, high carbon content yield good coke and vice versa. However, the samples are not suitable for coking because of the high volatile matter. Calorific value varies from $(5469-6452 \mathrm{kcal} / \mathrm{kg})$ indicating that all the samples have high calorific value which is reflected in the high fixed carbon and low ash content. 
The samples are better for fuel purposes than coking. Figure 6 reveals a direct proportional relationship between the depth of the coal samples and its fixed carbon content, the fixed carbon content increases as the depth of burial increases with the exception of sample MG1A (Table 1).

From this study, the coal samples contain low to medium moisture content, high volatile matter and low ash. The coals are high in volatiles $(>31 \%)$, with fixed carbon $(<50 \%)$. Based on these results, the coals are sub-bituminous suitable for combustion, power generation and fuel purposes. It is important to note that ash, volatile matter, fixed carbon and calorific value are all a function of original coal bed composition than rank.

\subsection{Major Element Geochemistry}

The major elements geochemistry of the coal samples analyzed were used to infer the depositional environment and acid generation potential of the coal ash using A-K-F ternary plot [22] and the A -CNK-FM ternary plot [23] (Figure 7 and Figure 8) respectively. Samples MG1A, MG1W and MG2H were analyzed

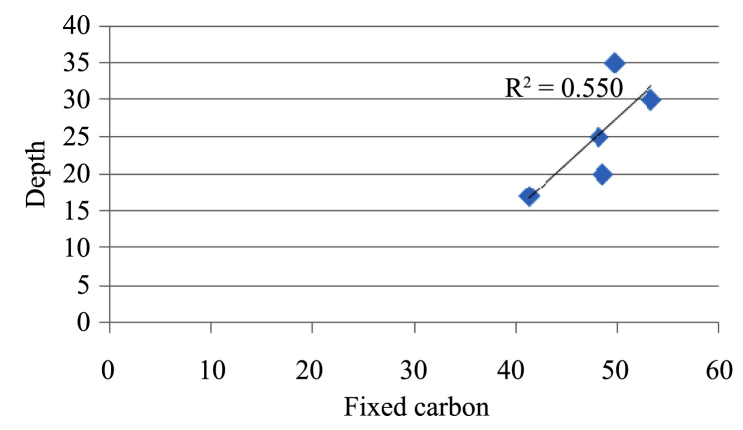

Figure 6. Correlation between stratigraphic depth and fixed carbon. The fixed carbon is directly proportional to the depth, the fixed carbon increases with stratigraphic depth.

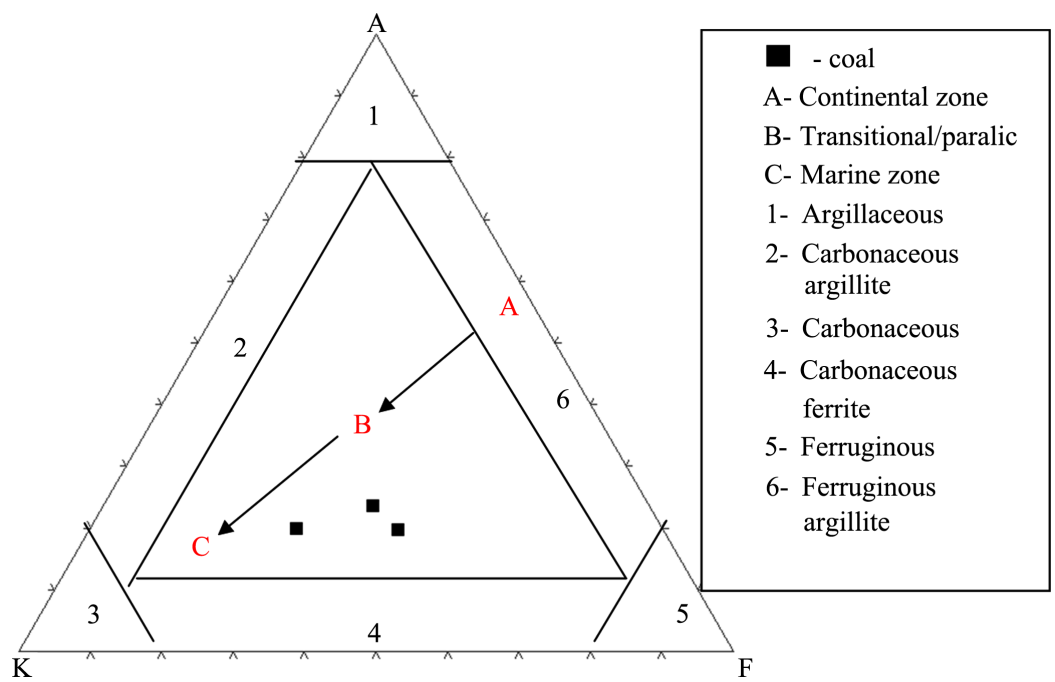

Figure 7. $\mathrm{Al}_{2} \mathrm{O}_{3}-\left(\mathrm{K}_{2} \mathrm{O}+\mathrm{CaO}+\mathrm{MgO}\right)-\left(\mathrm{Fe}_{2} \mathrm{O}_{3}+\mathrm{MgO}\right)$ [AKF]. Ternary plot of Maiganga coal samples. The coals are plotted in the Transitional/Paralic depositional environments [22]. 


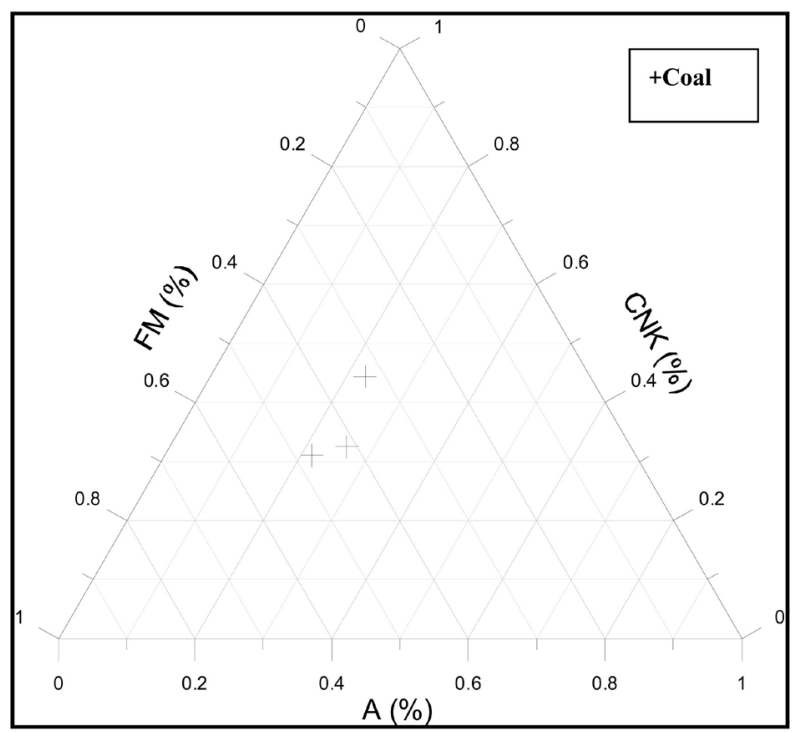

Figure 8. A-CNK-FM plot for the Maiganga coal samples which indicates low proportion of base neutralizing cation. $\mathrm{A}=\mathrm{Al}_{2} \mathrm{O}_{3}, \mathrm{CNK}=\mathrm{CaO}+\mathrm{Na}_{2} \mathrm{O}+\mathrm{K}_{2} \mathrm{O}$ and $\mathrm{FM}=\mathrm{Fe}_{2} \mathrm{O}_{3}+$ $\mathrm{MgO}$ [23].

for major elements ( $\mathrm{Si}, \mathrm{Al}, \mathrm{Fe}, \mathrm{Mn}, \mathrm{Mg}, \mathrm{Ca}, \mathrm{Na}, \mathrm{K}, \mathrm{Ti}$ and $\mathrm{P}$ ) and their oxides were recorded in percentages. The $\mathrm{SiO}_{2}$ value range from $1.02 \%-3.38 \%$, while $\mathrm{Al}_{2} \mathrm{O}_{3}$ range from $0.53 \%-0.79 \%$, the average value of $\mathrm{CaO}$ and $\mathrm{Fe}_{2} \mathrm{O}_{3}$ are $1.02 \%$ and $0.90 \%$ respectively (Table 2). The low average value of $\mathrm{Fe}_{2} \mathrm{O}_{3}(0.90)$ suggest the absence or low content of iron bearing mineral like pyrite and the low $\mathrm{Fe}_{2} \mathrm{O}_{3}$, $\mathrm{TiO}_{2}$ and $\mathrm{MgO}$ probably suggests presence of kaolinite. The alkalis $\mathrm{K}_{2} \mathrm{O}, \mathrm{Na}_{2} \mathrm{O}$ as well as $\mathrm{CaO}, \mathrm{MgO}$ and $\mathrm{MnO}$ which occur in relatively insignificant proportions are in the range of $(<0.01 \%$ to $1.11 \%)$ which suggest high degree of weathering, under tropical conditions.

The coal samples have extremely low $\mathrm{SiO}_{2}$ contents of about $2.38 \%$ average and are primarily since it consists basically of volatile constituents that were combusted as evident from the average loss on ignition (94.6\%). The depositional environment deduced from AKF plots showed a gradual transition from continental to transitional environments and to marine environments. However, the samples were deposited under transitional or paralic depositional setting [22] (Figure 7).

The acid producing potential of the coal ash was inferred from the A-CNK-FM ternary plot (Figure 8) which shows the proportions of $\mathrm{Al}_{2} \mathrm{O}_{3}, \mathrm{CaO}+\mathrm{Na}_{2} \mathrm{O}+$ $\mathrm{K}_{2} \mathrm{O}$ and $\mathrm{Fe}_{2} \mathrm{O}_{3}+\mathrm{MgO}$ [23]. The $\mathrm{A}-\mathrm{CNK}-\mathrm{FM}$ ternary plot was used to show correlation between the coal ash compositions grouped into basic, fluxing acidic and nonfluxing acidic oxides, with ash fusion temperatures. The A -CNK-FM ternary plot of the three coal ash samples (Figure 8) indicates the samples have low proportion of base neutralizing cations (CNK). The chemical index of alteration (CIA) and sulphur content can also give clue on the potential of the ash to generate acid [24]. The CIA was calculated by the formula $\left(\mathrm{Al}_{2} \mathrm{O}_{3} /\left(\mathrm{Al}_{2} \mathrm{O}_{3}+\mathrm{CaO}\right.\right.$ $\left.+\mathrm{Na}_{2} \mathrm{O}+\mathrm{K}_{2} \mathrm{O}+\mathrm{MgO}\right) \times 100$ [25]. Acid producing coal ash will have CIA value 
greater than 20\% (hence low base proportion in ash) and high reactive sulphur content [24]. However, in the samples analyzed, the CIA range from $40 \%-44 \%$ indicating apparent acid generating potential. This is corroborated by the moderate sulphur content ranging from $(0.05 \%-0.1 \%)$ with an average of $(0.07 \%)$.

\subsection{Trace Element Geochemistry and Environmental Implications}

The trace element geochemistry of the investigated coal samples was employed to decipher the environmental effect and impact on coal utilization via combustion and to determine the elements that were associated with the coal ash in the organic matrix and in mineral phase. Nineteen (19) trace elements were obtained namely Ba, Be, Co, Cs, Ga, Ge, Hf, Nb, Rb, Sn, Sr, Ta, Th, U, V, Y. W, Zr, $\mathrm{Ni}$ and $\mathrm{Sc}$ (Table 3). The compatible trace elements include $\mathrm{Ni}, \mathrm{Cr}$ and $\mathrm{Zn}$ while $\mathrm{Ba}, \mathrm{Co}, \mathrm{Cs}, \mathrm{Au}, \mathrm{Br}, \mathrm{Ga}, \mathrm{Zr}, \mathrm{Ge}, \mathrm{Hf}, \mathrm{Rb}, \mathrm{Sb}, \mathrm{Sc}, \mathrm{Se}, \mathrm{Sr}, \mathrm{Ta}$, Th and $\mathrm{U}$ are incompatible trace elements. The concentrations of trace elements in the samples are low except Nickel, Copper, Barium, Strontium and Zircon. The release of some of these element's e.g $\mathrm{Sb}, \mathrm{As}, \mathrm{F}, \mathrm{Hg}, \mathrm{Pb}, \mathrm{Se}$, Th and $\mathrm{U}$ into the environment through coal combustion may pose serious environmental problem if they occur in significant amounts [26]. It is important to consider the potential environmental impact of trace elements released by coal utilization. A number of studies have shown that trace elements from coal combustion and combustion residues increase the concentration of toxic elements in the biosphere, in some cases resulting in negative health impacts on plants, animals and humans [27] [28].

Nickel concentration of the investigated coal samples ranges from $111-205$ ppm with an average of 146 ppm, Cu (122 - 176 ppm, avg 142 ppm), Ba (65 - 91 ppm, avg 74 ppm), Sr (51 - 65 ppm, avg 56 ppm), Zr (8 - 28 ppm, avg 18 ppm) other trace elements have low values (Table 3 ). The average concentrations of these elements are lower when compared to world coals and therefore have lesser negative impact to the environments (Table 5).

High concentrations of chlorine, fluorine, and vanadium in the feed coal may

Table 5. Average concentration of some trace elements in Maiganga coal compared with average world coals.

\begin{tabular}{ccc}
\hline Elements & Present study $(\mathrm{ppm})$ & World $^{\mathrm{c}}(\mathrm{ppm})$ \\
\hline $\mathrm{Cr}$ & $<5$ & 16 \\
$\mathrm{Hf}$ & 0.4 & 1.2 \\
$\mathrm{Se}$ & $<3$ & 1.3 \\
$\mathrm{Zr}$ & 18 & 36 \\
$\mathrm{Zn}$ & 1.7 & 23 \\
$\mathrm{Sr}$ & 56 & 110 \\
$\mathrm{Ba}$ & 74 & 150 \\
\hline
\end{tabular}

c from [35]. 
cause corrosion of the combustion equipment [29] [30] [31] [32]. High vanadium coals may cause agglomeration in fluidised bed combustion boilers [33]. In this study, the concentration of vanadium is low $(<5 \mathrm{ppm})$. It has long been known that sulphur from coal combustion can cause acid rain [34]. Similarly, chlorine and fluorine in coal can also cause acidic emissions. In the samples analyzed, the low concentration of vanadium indicates low corrosion and agglomeration potential in combustion boilers [33]. Also, the average concentrations of trace elements like $\mathrm{Zn}$ (1.7 ppm), Se (<3 ppm), Hf (0.4 ppm), Br (3.17 ppm), $\mathrm{Cr}(<5 \mathrm{ppm})$ and $\mathrm{S}(0.07 \%)$ are moderate in the samples.

Coal ash could be dominated by either clastics (clays, quartz or zircon) high in $\mathrm{Al}$ and $\mathrm{Si}$ or by meteoric precipitate (pyrite) high in iron. A coal ash consisting of Al rich clay and clastic detritus could contain Hf bearing zircon and therefore would display a positive correlation between $\mathrm{Hf} / \mathrm{Zr}$ and other bearing lithophile element. Low Aluminum concentration in coal ash will tend to be high in iron indicating a far less detrital material including zircon. In this study, the significant positive correlation value $(\mathrm{r}=0.85)$ generated from plot of $\mathrm{Hf} / \mathrm{Zr}$ (Figure 9) indicates that the coal samples from Maiganga consist of $\mathrm{Al}$ rich clay probably kaolinite and clastic detritus (quartz and zircon). Elemental cross plot may be used to determine whether elements exist in organic matrix of the coal or as discrete mineral phases. The element chlorine and vanadium are thought to exist in inorganic matrix of the coal but could be derived from minerals halite and illite respectively. Cross plot of vanadium against coal ash (Figure 10) having correlation value of $(r=0.52)$ indicate low vanadium concentration associated with the ash. This probably suggests an organic affinity for chlorine and a mineral affinity for vanadium.

\subsection{Rare Earth Element Geochemistry}

Rare earth element geochemistry was employed to determine the depositional condition and the vegetation type that form the coal bed. They are effective indicators of sediment source when compared to Upper Continental Crust (UCC), Oceanic Crust (OC) and mantle materials.

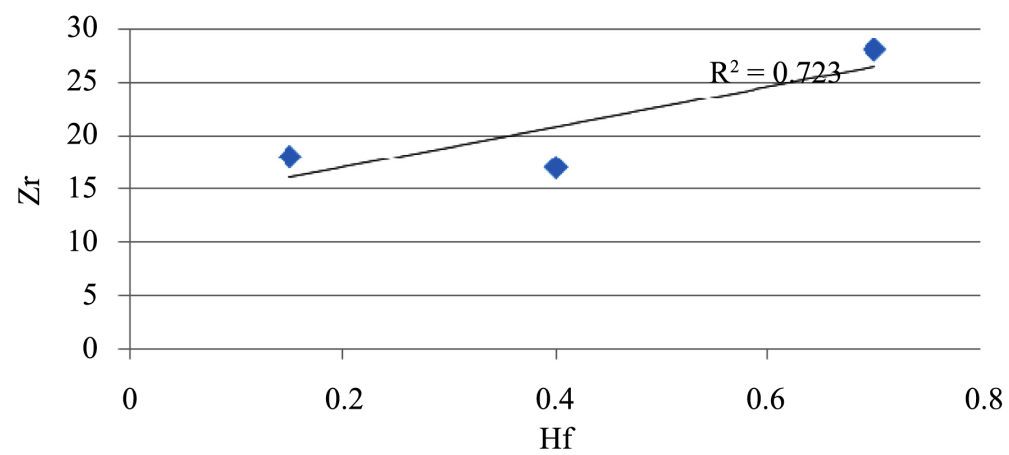

Figure 9. Plot of Hafnium (Hf) against Zirconium (Zr). The significant positive correlation value $(r=0.85)$ indicates that the coal samples from Maiganga consist of Al rich clay probably kaolinite and clastic detritus. 


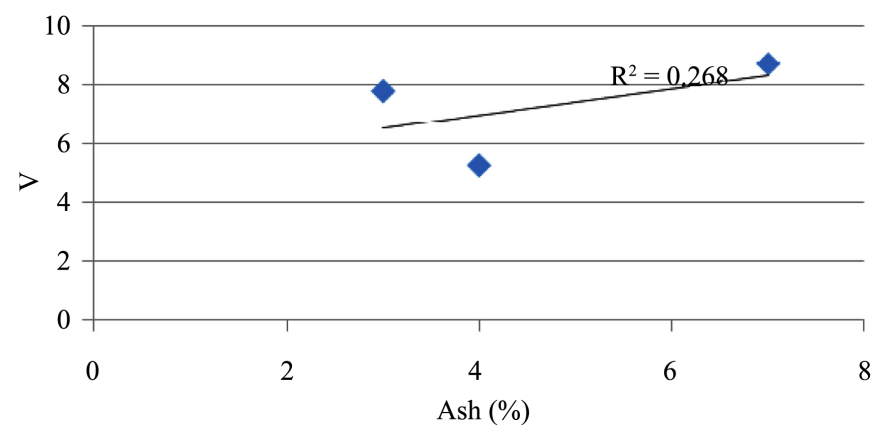

Figure 10. Plot of Vanadium (V) against Ash. Correlation value of $(r=0.52)$ suggests an organic affinity for Chlorine and a mineral affinity for Vanadium.

The REE comprises the series of metals with atomic numbers 57 to $71-\mathrm{La}$ to Lu. Typically, the low atomic number members (La-Pr) of the series are termed the light rare earth elements (LREE). Those with the higher atomic numbers $(\mathrm{Er}-\mathrm{Lu})$ are the heavy rare earth elements (HREE) while less commonly the middle members of the group, $\mathrm{Sm}$ to Ho, are known as the middle rare earth elements (MREE). The REE for the samples were normalized to a standard. The standard used for this work is that of [36].

The normalized REE (concentrations in $\mathrm{ppm}$ ) were plotted against the atomic numbers of the REE which gave a REE pattern (Figure 11). Europium anomalies may be quantified by comparing the measured concentration with an expected concentration obtained by interpolating between the normalized values of $\mathrm{Sm}$ and $\mathrm{Gd}$. Thus, the ratio of $\mathrm{Eu}$ is a measure of the Europium anomaly and a value greater than 1.0 indicates a positive Europium anomaly while the value less than 1.0 is a negative anomaly. The normalized values, the Europium and Cerium anomalies value were calculated and the result presented in (Table 6).

$\mathrm{Ce} / \mathrm{Ce}^{*}$ is a geochemical proxy used for determining the environmental conditions at the time of deposition. Values greater than (1.0) tentatively depict an oxidizing environment [37] [38]. This study shows that there is enrichment of LREE over HREE and the europium anomaly (average of 0.71 ) is less than 1 indicating negative anomaly, this is supported up by the REE patterns for the samples (Figure 11). The Cerium anomaly is also negative for the sample MG1W and $\mathrm{MG} 2 \mathrm{H}$ (0.74 and 0.89 ) respectively indicating reducing environment while MG1A has Positive Ce anomaly with values (1.06) depicting oxidizing condition.

\subsection{The Original Plant That Form the Coal}

Identification of the original plants that formed a coal is sometimes a difficult process, it is generally thought that most coals originated from trees and peat, but also that some have originated from algae [39]. The trace elements in a coal can contain information on the origins of the coal and on the conditions of coalification because the trace elements in coals principally come from the plants that formed the coal and from the surrounding environment. Rare earth elements (REEs) in coal have been identified as a group of special significance [40] [41] [42] [43]. 
Table 6. Normalized values, europium and cerium anomalies of Maiganga coal samples.

\begin{tabular}{|c|c|c|c|c|c|c|c|c|c|c|c|c|c|c|c|c|}
\hline \multirow{2}{*}{$\begin{array}{c}\text { Sample } \\
\text { code }\end{array}$} & \multicolumn{16}{|c|}{ ppm } \\
\hline & $\mathrm{La}$ & $\mathrm{Ce}$ & Pr & $\mathrm{Nd}$ & $\mathrm{Sm}$ & $\mathrm{Eu}$ & Gd & $\mathrm{Tb}$ & Dy & Ho & Er & $\mathrm{Tm}$ & $\mathrm{Yb}$ & $\mathrm{Lu}$ & $\mathrm{Eu} / \mathrm{Eu}^{*}$ & $\mathrm{Ce} / \mathrm{Ce}^{*}$ \\
\hline MG1A & 3.24 & 3.19 & 3.22 & 2.66 & 2.05 & 1.37 & 1.54 & 1.28 & 1.67 & 1.28 & 1.50 & 1.25 & 1.50 & 0.05 & 0.73 & 1.06 \\
\hline MG1W & 9.70 & 6.04 & 4.46 & 3.13 & 2.05 & 1.10 & 1.15 & 1.49 & 1.00 & 0.77 & 1.00 & 0.94 & 1.00 & 0.04 & 0.72 & 0.74 \\
\hline MG2H & 7.94 & 6.04 & 5.04 & 3.60 & 2.05 & 1.23 & 1.54 & 1.70 & 1.00 & 0.90 & 1.00 & 0.94 & 1.00 & 0.04 & 0.69 & 0.89 \\
\hline
\end{tabular}

$\mathrm{Eu} / \mathrm{Eu}^{*}=\mathrm{Eu}_{\mathrm{N}} / \sqrt{\mathrm{Sm}_{\mathrm{N}} * \mathrm{Gd}_{\mathrm{N}}} ; \mathrm{Ce} / \mathrm{Ce}^{*}=5 \mathrm{Ce} /\left(4 \mathrm{La}_{\mathrm{N}}+\mathrm{Sm}_{\mathrm{N}}\right) ;$ Note: ${ }_{\mathrm{N}}$ and ${ }^{*}$ indicate chondrite normalized elements.

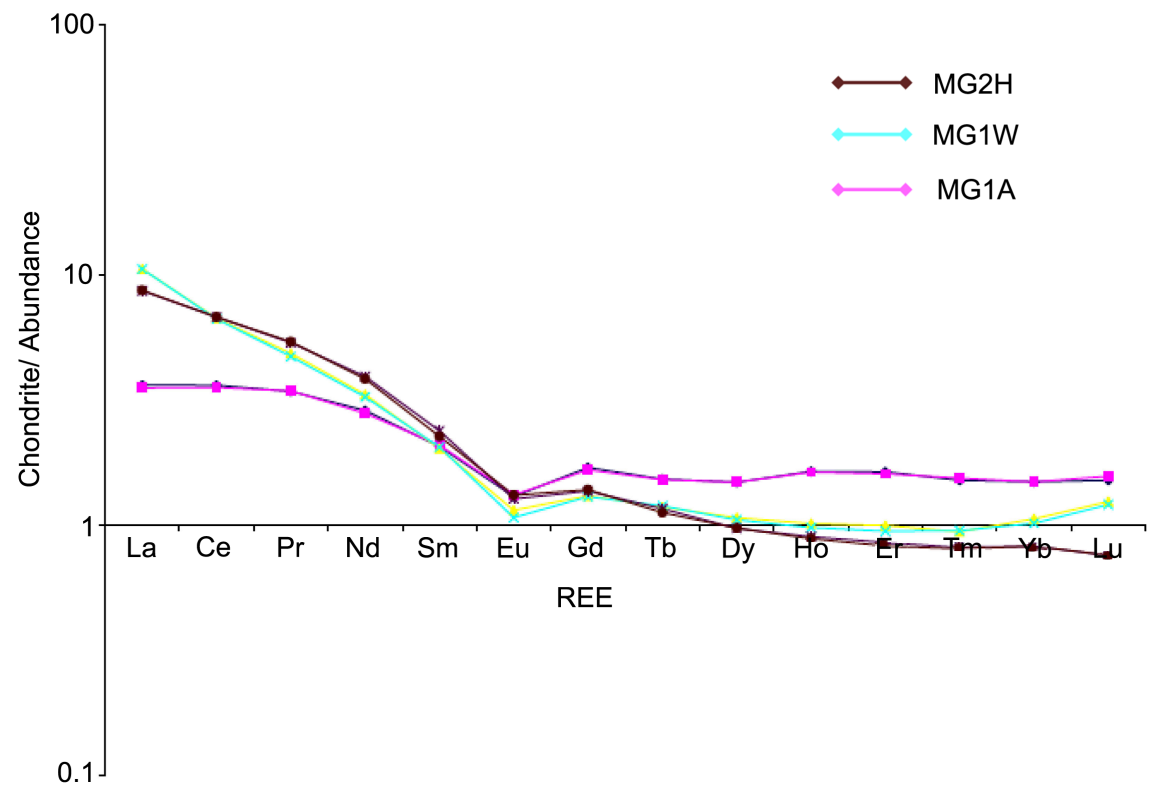

Figure 11. Rare Earth Elements (REE) Pattern for the coal samples. The pattern indicates negative europium anomaly for the coal samples.

REEs in coals can originate from the original plants that formed the coal, from soil minerals, and from water. The percentage of REEs inherited from the original plants depends on the nature of the original plants that formed the coals and can vary since different species of plants contain different levels of REEs [44] [45].

It has been previously reported that negative Ce anomalies are normally observed in soil-grown plants, and that the mineral fraction in soils either does not show a negative Ce anomaly or shows a slightly positive Ce anomaly [44]. REEs in terrestrial soil-grown plants could originate from silicate minerals [44] whereas those in algae originate partly from water and partly from particles suspended in the water. Thus, the relative abundance of REEs in terrestrial soil-grown plants, peat vegetation, and algae are distinct from each other. Soil-grown plants and algae are known to have Ce anomalies in their REE patterns, whereas peat vegetation has no Ce anomaly [44] [45]. In this study, the extent of the cerium anomaly $\left(A_{\mathrm{Ce}}\right)$ is expressed numerically by the formula $A_{\mathrm{Ce}}=\log \left(\mathrm{Ce} / \mathrm{Ce}^{\star}\right)$.

The value of $A_{\mathrm{Ce}}$ is quantified as the logarithm of $\mathrm{Ce} / \mathrm{Ce}^{\star}$ 
Table 7. Ce anomalies with corresponding plant forming coal (modified after [44] [45]).

\begin{tabular}{ccc}
\hline Plants & Ce anomaly & A (Ce) anomaly (Present Study) \\
\hline Peat Vegetation* & & \\
Sphagnum L. $10 \mathrm{~cm}$ & 0.01 & 0.02 (MG1A) \\
Sphagnum L. $30 \mathrm{~cm}$ & 0.01 & \\
Carex $L$. & 0.01 & -0.13 (MG1W) \\
Trunk of tree ${ }^{* *}$ & & \\
Populous sieboldii & -0.6 & \\
Mangrove & -0.15 & \\
Taxodium japonicum & -0.25 & \\
Thea sinensis & -0.54 & \\
Stem/ trunk of other soil grown plant! & & -0.05 (MG2H) \\
Matteuccia spp & -0.50 & \\
Sasa nipponica & -0.16 & \\
Vicia villosa & -0.08 &
\end{tabular}

$$
\begin{gathered}
\mathrm{MG1A}=\log (1.06)=0.025 \\
\mathrm{MG1W}=\log (0.74)=-0.130 \\
\mathrm{MG} 2 \mathrm{H}=\log (0.89)=-0.050
\end{gathered}
$$

REEs in sample MG1A (seam B) originated from peat vegetation with Cerium anomaly being positive, with value of (0.02) and no Ce anomaly in the REE pattern. This may be due to low $\mathrm{PH}$ value of the water in the peatland soil and redox potential to oxidize $\mathrm{Ce}^{3+}$ to $\mathrm{Ce}^{4+}[45]$. This is supported by the $\mathrm{Ce} / \mathrm{Ce}^{*}$ value slightly greater than 1.0 (positive) (Table 6) indicating oxidizing condition and the original plant that form the peat was probably (Sphagnum L. $10 \mathrm{~cm}$ or Carex $L$.). Coal seam A (sample MG1W and MG2H) has negative Ce anomaly value A (Ce) of $(-0.13$ and -0.05$)$ respectively (Table 7$)$ indicating mangrove and Vicia villossa for the soil grown plants. The REEs in terrestrial soil grown plant originate from the silicate minerals probably kaolinite since it has negative cerium anomaly.

\section{Conclusions}

The investigated coals are thermal coals of sub-bituminous rank. They are easier to ignite and give greater flame stability due to the higher volatile matter content and suitable for combustion, fuelling and power generation.

The coals samples have potential of generating acid as indicated by the CIA value greater than $20 \%$. The moderate ash, sulphur concentration of $<1 \%$ of the coal suggests peat accumulation in a raised mire in a fluvial paralic/transitional depositional environment. The coals have an association with inorganic minerals like quartz, illite, kaolinite and little sulphur. 
The study shows the original plants that form the peat are Sphagnum $L$ or Carex $L$ for sample MG1A (seam A) in oxidizing condition. Seam B coals are however characterized by trunk of soil grown mangrove plant and Vicia villossa.

\section{Acknowledgements}

The authors express their gratitude to the management of Ashaka Cement factory for providing logistics and support during collection of samples at the coal mine. We also acknowledge the anonymous reviewer for their contributions.

\section{Conflicts of Interest}

The authors declare no conflicts of interest regarding the publication of this paper.

\section{References}

[1] Olade, M.A. (1975) Evolution of Nigeria's Benue Trough (Aulacogen): A Tectonic Model. Geological Magazine, 112, 575-583. https://doi.org/10.1017/S001675680003898X

[2] Benkhelil, J. (1989) The Origin and Evolution of the Cretaceous Benue Trough (Nigeria). Journal of African Earth Sciences (and the Middle East), 8, 251-282. https://doi.org/10.1016/S0899-5362(89)80028-4

[3] Wright, J.B. (1968) South Atlantic Continental Drift and the Benue Trough. Tectonophysics, 6, 301-310. https://doi.org/10.1016/0040-1951(68)90046-2

[4] Obaje, N.G., Wehner, H., Scheeder, G., Abubakar, M.B. and Jauro, A. (2004) Hydrocarbon Prospectivity of Nigeria's Inland Basins: From the Viewpoint of Organic Geochemistry and Organic Petrology. American Association of Petroleum Geologists Bulletin, 88, 325-353.

[5] Obaje, N.G., Attah, D.O., Opeloye, S.A. and Moumouni, A. (2006) Geochemical Evaluation of the Hydrocarbon Prospects of Sedimentary Basins in Northern Nigeria. Geochemical Journal, 40, 227-243.

[6] Jauro, A., Obaje, N.G., Agho, M.O., Abubakar, M.B. and Tukur, A. (2007) Organic geochemistry of Cretaceous Lamza and Chikila Coals, Upper Benue Trough, Nigeria. Fuel, 86, 520-532. https://doi.org/10.1016/j.fuel.2006.07.031

[7] Onoduku, U.S., Okosun, E.A. and Akande, W.G. (2013) An Assessment of the Hydrocarbon Potential of the Gombe Formation, Upper Benue Trough, Northeastern Nigeria: Organic Geochemical Point of View. Earth Science Research, 2, 203-213. https://doi.org/10.5539/esr.v2n2p203

[8] Jimoh, A.Y. and Ojo, O.J. (2016) Rock Eval Pyrolysis and Organic Petrographic Analysis of the Maastrichtian Coals and Shales at Gombe, Gongola Basin, Northeastern Nigeria. Arabian Journal of Geosciences, 9, Article No. 443. https://doi.org/10.1007/s12517-016-2467-x

[9] Zarboski, P., Ugodunlunwa, F., Idornigie, A., Nnabo, P. and Ibe, K. (1997) Stratigraphy and Structure of the Cretaceous Gongola Basin, Northeastern Nigeria. Bulletin des Centres de Recherches Exploration-Production Elf-Aquitaine, 21, 153-185.

[10] Guiraud, M. (1990) Tectono-Sedimentary Framework of the Early Cretaceous Continental Bima Formation (Upper Benue Trough, NE Nigeria). Journal of African Earth Sciences (and the Middle East), 10, 341-353. 
https://doi.org/10.1016/0899-5362(90)90065-M

[11] Whiteman, A.J. (1982) Nigeria: Its Petroleum Geology, Resources and Potential. Graham and Trotman, London, 381. https://doi.org/10.1007/978-94-009-7361-9

[12] Carter, J.D., Barbar, W., Tait, E.A. and Jones, G.P. (1963) The Geology of Parts of Adamawa, Bauchi and Borno Provinces in Northeastern Nigeria. Geological Survey of Nigeria Bulletin, 30, 1-108.

[13] Wuyep, E.O. and Obaje, N.G. (2012) Petrographic Evaluation of the Ranks and Technological Applications of Some Coal Deposits in the Anambra Basin and Middle Benue Trough of Nigeria. Journal of Earth Science and Engineering, 2, 220-234.

[14] Obaje, N.G., Amadi, A.N., Aweda, A.K., Umar, U.M. and Shuaibu, I. (2018) Processing Nigerian Coal Deposits for Energy Source. Environmental Earth Sciences, 77, Article No. 176. https://doi.org/10.1007/s12665-018-7362-1

[15] Ehinola, O.A. and Adene, T.M. (2018) Preliminary Investigation on Acid Generating Potential of Coals from Benue Trough, Nigeria. Petroleum \& Coal, 50, 19-26.

[16] Abubakar, M.B., Obaje, N.G., Luterbacher, H.P., Dike, E.F.C. and Ashraf, A.R. (2006) A Report on the Occurrence of Albian-Cenomanian Elater-Bearin Pollen in Nasara-1 Well, Upper Benue Trough, Nigeria. Biostratigraphic and Palaeoclimatological Implications. Journal of African Earth Sciences, 45, 347-354. https://doi.org/10.1016/j.jafrearsci.2006.03.008

[17] American Society for Testing and Materials (1974) Standard Specifications for Classification of Coals by Rank, ASTM Designation: D388-66 (Reapproved 1972). In: Gaseous Fuels; Coal and Coke; Atmospheric Analysis: American Society for Testing Materials, pt. 26, 54-58.

[18] Mackowsky, M.Th. (1982) The Application of Coal Petrography in Technical Processes. In: Stach, E., Mackowsky, M.Th., Teichmuller, M., Taylir, G.H., Chandra, D. and Teichmuller, R., Eds., Stach's Textbook of Coal Petrology, Gebruder Borntraeger, Berlin, 413-483.

[19] Fatoye, F.B. and Gideon, Y.B. (2013) Appraisal of the Economic Geology of Nigerian Coal Resources. Journal of Environment and Earth Sciences, 3, 25-31.

[20] Obaje N.G. and Hamza, H. (2000) Liquid Hydrocarbon Source-rock Potential of Mid-Cretaceous Coals and Coal Measures in the Middle Benue Trough of Nigeria. International Journal Earth Sciences, 89, 130-139. https://doi.org/10.1007/s005310050321

[21] Raask, E. (1985) Mineral Impurities in Coal Combustion Behavior, Problems and Remedial Measures. Hemisphere Publishing, New York, 484 p.

[22] Englund, J.-O. and Jørgensen, P. (1973) A Chemical Classification System for Argillaceous Sediments and Factors Affecting Their Composition. Geologiska Föreningen i Stockholm Förhandlingar, 95, 87-97. https://doi.org/10.1080/11035897309455428

[23] Nesbitt, H.W., Young, G.M., McLannan, S.M. and Keays, R.R. (1996) Effects of Chemical Weathering and Sorting on the Petrogenesis of Siliciclastic Sediments, with Implication for Provenance Studies. The Journal of Geology, 104, 525-542. https://doi.org/10.1086/629850

[24] Campbell, R.N., Linndsay, P. and Clemens, A.H. (2001) Acid Generating Potential of Waste Rock and Coal Ash in New Zealand Coal Mines. International Journal of Coal Geology, 45, 163-179. https://doi.org/10.1016/S0166-5162(00)00031-8

[25] Nesbitt, H.W. and Young, G.M. (1982) Early Proterozoic Climate and Plate Motion Inferred from Major Element Chemistry of Lutites. Nature, 299, 715-717. 
https://doi.org/10.1038/299715a0

[26] Skodras, G., Orfanoudaki, Th., Kakaras, E. and Sakellaropoulous, G.P. (2002) Production of Special Activated Carbon from Lignite for Environmental Purposes. Fuel Processing Technology, 77-78, 75-87. https://doi.org/10.1016/S0378-3820(02)00062-0

[27] Panov, B.S., Dudik, A.M., Shevchenko, O.A. and Matlak, E.S. (1999) On Pollution of the Biosphere in Industrial Areas: the Example of the Donets Coal Basin. International Journal of Coal Geology, 40, 199-210. https://doi.org/10.1016/S0166-5162(98)00069-X

[28] Zheng, B., Ding, Z., Huang, R., Zhu, J., Yu, X., Wang, A., Zhou, D., Mao, D. and Su, H. (1999) Issues of Health and Disease Relating to Coal Use in Southwestern China. International Journal of Coal Geology, 40, 119-132. https://doi.org/10.1016/S0166-5162(98)00064-0

[29] Caswell, S.A., Holmes, I.F. and Spears, D.A. (1984) Water-Soluble Chlorine and Associated Major Cations from the Coals and Mudrocks of the Cannock and North Staffordshire Coalfields. Fuel, 63, 774-781.

https://doi.org/10.1016/0016-2361(84)90067-X

[30] Liu, K., Xie, W., Li, D., Pan, W.P., Riley, J.T. and Riga, A. (2000) The Effect of Chlorine and Sulphur on the Composition of Ash Deposits in a Fluidised Bed Combustion System. Energy \& Fuels, 79, 963-972. https://doi.org/10.1021/ef990197k

[31] Shearer, J.C., Moore, T.A., Vickridge, I.C. and Deely, J.M. (1997) Tephra as a Control on Trace Element Distribution in Waikato Coals. Proceedings of 7 th $\mathrm{New}$ Zealand Coal Conference, Wellington, New Zealand, 1997, 505.

[32] Spears, D.A. and Zheng, Y. (1999) Geochemistry and Origin of Elements in Some UK Coals. International Journal of Coal Geology, 38, 161-179. https://doi.org/10.1016/S0166-5162(98)00012-3

[33] Anthony, E.J. and Jia, L. (2000) Agglomeration and Strength Development of Deposits in CFBC Boilers Firing High-Sulphur Fuels. Fuel, 79, 1933-1942. https://doi.org/10.1016/S0016-2361(00)00054-5

[34] Bouska, V. and Pesek, J. (1999) Quality Parameters of Lignite of the North Bohemian Basin in the Czech Republic in Comparison with the World Average Lignite. International Journal of Coal Geology, 40, 211-235. https://doi.org/10.1016/S0166-5162(98)00070-6

[35] Ketrich, M.P. and Yudovich, Y.E. (2009) Estimations of Clarkes for Carbonaceous Biolithes: World Average for Trace Element Contents in Black Shales and Coals. International Journal of Coal Geology, 78, 135-148. https://doi.org/10.1016/j.coal.2009.01.002

[36] Wakita, H., Ray, P. and Schmitt, R.A. (1971) Abundances of the 14 Rare Earth Elements and 12 Other Trace Elements in Apollo 12 Samples: Five Igneous and One Breccia Rocks and Four Soils. Proceedings of the 2nd Lunar Science Conference, 1971 Oxford Pergamon Press, 1319-1329.

[37] McDaniel, D.K., Hemming, S.R., Mclennan, S.M. and Hanson, G.N. (1994) Resetting of Neodymium Isotopes and Redistribution of REE'S during Sedimentary Processes: The Early Proterozoic Chelmsford Formation, Sudbury Basin, Ontario, Canada. Geochima Cosmochimica Acta, 58, 931-941. https://doi.org/10.1016/0016-7037(94)90516-9

[38] Milodowski, A.E. and Zalasiewkz, J.A. (1991) Redistribution of Rare Earth Elements during Diagenesis of Eurbidice/Hemipelagic Mudrock Sequences and Age from Central Wales. In: Mortan, A.C., Todd, S.P. and Houghton, P.D.W., Eds., Geologi- 
cal Society London Special Publications, Vol. 57, Geological Society, London, 101-124. https://doi.org/10.1144/GSL.SP.1991.057.01.10

[39] Cross, A.T. and Phillips, T.L. (1990) Coal-Forming Plants through Time in North America. International Journal of Coal Geology, 16, 1-46.

https://doi.org/10.1016/0166-5162(90)90012-N

[40] Eskenazy, G. (1987) Rare Earth Elements and Yttrium in Lithotypes of Bulgarian Coals. Organic Geochemistry, 11, 83-89. https://doi.org/10.1016/0146-6380(87)90030-1

[41] Birk, D. and White, J.C. (1991) Rare Earth Elements in Bituminous Coals and Underclays of the Sydney Basin, Nova Scotia: Element Sites, Distribution and Mineralogy. International Journal of Coal Geology, 19, 219-251.

https://doi.org/10.1016/0166-5162(91)90022-B

[42] Querol, X., Whateley, M.K.G., Fernández-Turiel, J.L. and Tuncali, E. (1997) Geological Controls on the Mineralogy and Geochemistry of the Beypazari Lignite, Central Anatolia, Turkey. International Journal of Coal Geology, 33, 255-271. https://doi.org/10.1016/S0166-5162(96)00044-4

[43] Mukhopadhyay, P.K., Goodarzi, F., Crandlemire, A.L., Gillis, K.S., MacNeil, D.J. and Smith, W.D. (1998) Comparison of Coal Composition and Elemental Distribution in Selected Seams of the Sydney and Stellarton Basins, Nova Scotia, Eastern Canada. International Journal of Coal Geology, 37, 113-141. https://doi.org/10.1016/S0166-5162(98)00020-2

[44] Fu, F.F., Akagi, T., Yabuki, S. and Iwaki, M. (2001) The Variation of REE (Rare Earth Elements) Patterns in Soil-Grown Plants: A New Proxy for the Source of Rare Earth Elements and Silicon in Plants. Plant and Soil, 235, 53-64. https://doi.org/10.1023/A:1011837326556

[45] Akagi, T., Fu, F.F. and Yabuki, S. (2002) Absence of Ce Anomaly in the REE Patterns of Peat Moss and Peat Grass in the Ozegahara Peatland. Geochemical Journal, 36, 113-118. https://doi.org/10.2343/geochemj.36.113 